\title{
Runella defluvii sp. nov., isolated from a domestic wastewater treatment plant
}

\author{
Shipeng Lu, ${ }^{1} \dagger$ Jung Ro Lee, ${ }^{1} \dagger$ Seung Hyun Ryu, ${ }^{1}$ Bok Sil Chung, ${ }^{1}$ \\ Woo-Seok Choe ${ }^{2}$ and Che Ok Jeon ${ }^{1}$ \\ ${ }^{1}$ Division of Applied Life Science, EB-NCRC, PMBBRC, Gyeongsang National University, \\ Jinju 660-701, Republic of Korea \\ ${ }^{2}$ Department of Chemical Engineering, Sungkyunkwan University, Suwon 440-746, Republic of \\ Korea
}

Correspondence

Che Ok Jeon

cojeon@gnu.ac.kr
The genus Runella, a member of the family 'Flexibacteraceae', was first proposed by Larkin \& Williams (1978). Currently, the genus contains three species, Runella slithyformis (Larkin \& Williams, 1978), Runella zeae (Chelius et al., 2002) and Runella limosa (Ryu et al., 2006). $R$. zeae was isolated from the stems of surface-sterilized Zea mays; in contrast, $R$. slithyformis and $R$. limosa were isolated from aquatic habitats, suggesting that aquatic environments may be important habitats for the genus Runella. Activated sludge processes have been used to remove organic compounds as well as nutrients from wastewater, and insight into the bacterial communities is a prerequisite for understanding activated sludge processes. Therefore, efforts have been made in our laboratory to isolate and characterize members of the bacterial community in activated sludge $(\mathrm{Lu}$ et al., 2006; Park et al., 2006, 2007). In this study, we describe another novel species belonging to the genus Runella isolated from an activated sludge process treating domestic sewage.

†These authors contributed equally to this work.

The GenBank/EMBL/DDBJ accession number for the $16 \mathrm{~S}$ rRNA gene sequence of strain EMB13 ${ }^{\top}$ is DQ372980.

A transmission electron micrograph of cells of strain $E M B 13^{\top}$ and $A P I$ $50 \mathrm{CH}$ utilization results for strain $\mathrm{EMB} 13^{\top}$ are available as supplementary material with the online version of this paper.
Strain $\mathrm{EMB} 13^{\mathrm{T}}$ was isolated from activated sludge of a domestic wastewater treatment plant in Pohang, Korea. A sludge sample was serially diluted with $1 \%(\mathrm{w} / \mathrm{v})$ saline solution, spread on R2A agar (Difco) and incubated at $20{ }^{\circ} \mathrm{C}$ for 5 days. Subcultivation was done on R2A agar at $30{ }^{\circ} \mathrm{C}$ for 3 days.

Gram staining was performed using the bioMérieux Gram stain kit according to the instructions of the manufacturer. Cell morphology and motility were studied using phasecontrast microscopy and transmission electron microscopy (JEM-1010; JEOL) as described by Jeon et al. (2005). Physiological characteristics of strain $\mathrm{EMB} 3^{\mathrm{T}}$ were examined by growing the isolate on R2A agar at different temperatures $\left(5-50{ }^{\circ} \mathrm{C}\right.$ at $5{ }^{\circ} \mathrm{C}$ intervals) and in $\mathrm{R} 2 \mathrm{~A}$ broth adjusted at different $\mathrm{pH}$ values $(\mathrm{pH} 5.0-10.0$ at $0.5 \mathrm{pH}$ unit intervals) (Gomori, 1955). Oxidase activity was tested by oxidation of $1 \%(\mathrm{w} / \mathrm{v})$ tetramethyl-p-phenylenediamine (Merck) and catalase activity was evaluated by production of oxygen bubbles in $3 \%(\mathrm{v} / \mathrm{v})$ aqueous hydrogen peroxide solution. Hydrolysis of tyrosine, Tweens 80 and 20, aesculin, casein, starch, gelatin and urea was assessed on R2A agar after 5 days incubation according to methods described previously (Lanyi, 1987; Smibert \& Krieg, 1994). Nitrate reduction was assessed according to the method of Lanyi (1987) and acid production from carbohydrates was 
tested as described by Leifson (1963). Additional enzyme activities and biochemical features were determined using API ZYM, API 20E and API 50CH kits as recommended by the manufacturer (bioMérieux) except that kits were incubated at $30{ }^{\circ} \mathrm{C}$. Strain $\mathrm{EMB} 13^{\mathrm{T}}$ on R2A agar formed slightly raised, circular, salmon-coloured colonies when grown at $30{ }^{\circ} \mathrm{C}$ for 3 days. Growth was observed at temperatures between 15 and $40{ }^{\circ} \mathrm{C}$, with an optimum growth temperature of $30-35{ }^{\circ} \mathrm{C}$. The strain grew at $\mathrm{pH} 6.0$ 9.5, with an optimum of $\mathrm{pH}$ 7.5-8.0. Cells of the isolate were non-motile rods $(0.5-0.9 \mu \mathrm{m}$ wide and $2.2-6.0 \mu \mathrm{m}$ long $)$ without flagella (Supplementary Fig. S1 available in IJSEM Online). Cells of strain EMB13 ${ }^{\mathrm{T}}$ were Gram-negative, oxidase-negative and catalase-positive and did not reduce nitrate to nitrite. The isolate was negative for production of indole, $\mathrm{H}_{2} \mathrm{~S}$ and acetoin and citrate utilization (API 20E). Anaerobic growth was not observed under anaerobic conditions over a 7 day incubation at $30{ }^{\circ} \mathrm{C}$ on $\mathrm{R} 2 \mathrm{~A}$ agar.

Analysis of fatty acid methyl esters was performed according to the instructions of the Microbial Identification System (MIDI; Microbial ID, Inc.). The DNA
$\mathrm{G}+\mathrm{C}$ content of strain $\mathrm{EMB} 13^{\mathrm{T}}$ was determined using an HPLC fitted with a reversed-phase column (GROM-SIL 100 ODS-2FE; GROM) according to the method of Tamaoka \& Komagata (1984). Analyses of polar lipids and isoprenoid quinones were carried out using the methods described by Komagata \& Suzuki (1987). The major respiratory lipoquinone of strain $\mathrm{EMB}^{\mathrm{T}}{ }^{\mathrm{T}}$ was menaquinone-7 (MK-7). The isolate contained iso- $\mathrm{C}_{15: 0}$ $(29.0 \%)$, summed feature $3\left(\mathrm{C}_{16: 1} \omega 7 c\right.$ and/or iso- $\mathrm{C}_{15: 0} 2$ $\mathrm{OH} ; 20.2 \%), \mathrm{C}_{16: 1} \omega 5 c(10.8 \%)$ and iso- $\mathrm{C}_{17: 0} 3-\mathrm{OH}$ $(9.2 \%)$ as the major fatty acids, which is similar to the profiles of other Runella species (Table 1). The G+C content of the genomic DNA was $40.1 \mathrm{~mol} \%$. The polar lipid profile of strain $\mathrm{EMB} 13^{\mathrm{T}}$ was dominated by a large amount of phosphatidylethanolamine, and small amounts of phosphatidylcholine and an unknown phospholipid (PL1) were also present, which shows that the isolate can be clearly differentiated from $R$. limosa EMB $111^{\mathrm{T}}$ (Table 1). Typical phenotypic characteristics of strain $\mathrm{EMB}^{\mathrm{T}}{ }^{\mathrm{T}}$ are summarized and compared with those of the type strains of closely related taxa in Table 1 and Supplementary Table S1. Some properties, such as the fatty acid composition, major

Table 1. Differential phenotypic characteristics of strain $E M B 13^{\top}$ and selected related species

Strains/species: 1, strain EMB13 ${ }^{\mathrm{T}}$ (data from this study); 2, R. limosa EMB111 ${ }^{\mathrm{T}}$ (Ryu et al., 2006); 3, R. slithyformis (Chelius \& Triplett, 2000); 4, R. zeae $\mathrm{NS}_{2}{ }^{\mathrm{T}}$ (Chelius et al., 2002); 5, Dyadobacter fermentans NS114 ${ }^{\mathrm{T}}$ (Chelius \& Triplett, 2000; Reddy \& Garcia-Pichel, 2005). +, Positive; -, negative; $\mathrm{W}$, weak reaction; NA, not available. All taxa are negative for nitrate reduction and gelatin hydrolysis.

\begin{tabular}{|c|c|c|c|c|c|}
\hline Characteristic & 1 & 2 & 3 & 4 & 5 \\
\hline Colony colour & Salmon & Salmon & Salmon & Salmon & Yellow \\
\hline Oxidase & - & - & + & + & + \\
\hline Catalase & + & + & $\mathrm{w}$ & + & + \\
\hline Starch hydrolysis & - & - & $\mathrm{W}$ & - & - \\
\hline \multicolumn{6}{|l|}{ Sole carbon sources for growth ${ }^{\star}$} \\
\hline Glycerol & + & - & - & - & $\mathrm{w}$ \\
\hline D-Arabitol & - & - & $\mathrm{w}$ & - & + \\
\hline L-Arabitol & - & - & - & - & $\mathrm{w}$ \\
\hline Dulcitol & - & - & $\mathrm{W}$ & $\mathrm{W}$ & $\mathrm{W}$ \\
\hline Inositol & - & - & $\mathrm{w}$ & $\mathrm{w}$ & + \\
\hline 5-Ketogluconate & $\mathrm{w}$ & + & - & $\mathrm{w}$ & + \\
\hline Methyl $\beta$-xyloside & + & - & + & + & + \\
\hline Maltose & - & + & + & + & + \\
\hline Trehalose & - & + & + & + & + \\
\hline Major cellular fatty acids & $\begin{array}{c}\text { iso- } \mathrm{C}_{15: 0}, \mathrm{C}_{16: 1} \omega 5 c, \\
\text { SF3 } \dagger\end{array}$ & iso- $\mathrm{C}_{15: 0}, \mathrm{C}_{16: 1} \omega 5 c, \mathrm{SF} 3$ & NA & $\mathrm{C}_{16: 1} \omega 5 c$, iso- $\mathrm{C}_{15: 0}, \mathrm{SF} 3$ & $\begin{array}{c}\text { iso- } \mathrm{C}_{15: 0}, \mathrm{C}_{16: 1} \omega 5 c, \\
\mathrm{C}_{16: 1} \omega 7 c\end{array}$ \\
\hline Major polar lipid $\ddagger$ & $\mathrm{PE}$ & PG & NA & NA & NA \\
\hline DNA G $+\mathrm{C}$ content $(\mathrm{mol} \%)$ & 40.1 & 44.5 & 49 & 49 & 48 \\
\hline
\end{tabular}

${ }^{\star}$ Results for $R$. limosa $\mathrm{EMB} 111^{\mathrm{T}}$ were obtained in this study.

$\dagger \mathrm{SF}$ 3, Summed feature 3, containing $\mathrm{C}_{16: 1} \omega 7 \mathrm{c}$ and/or iso- $\mathrm{C}_{15: 0} 2-\mathrm{OH}$.

\$PE, Phosphatidylethanolamine; PG, phosphatidylglycerol. 
lipoquinone and nitrate reduction, are in accordance with those of members of the genus Runella, whereas some others such as DNA G $+\mathrm{C}$ content and major polar lipids allow the differentiation of strain $\mathrm{EMB} 13^{\mathrm{T}}$ from closely related species.

Sequencing of the $16 \mathrm{~S}$ rRNA gene of strain $\mathrm{EMB} 13^{\mathrm{T}}$ was carried out as described previously (Lane, 1991). The PCR product was cloned using a TOPO cloning kit (Invitrogen) and sequenced. The resulting 16S rRNA gene sequence (1427 nucleotides) was compared with available 16S rRNA gene sequences from GenBank using the BLAST program (http://www.ncbi.nlm.nih.gov/BLAST/) to determine an approximate phylogenetic affiliation, and gene sequences were aligned with those of closely related species by using the CLUSTAL $\mathrm{W}$ software (Thompson et al., 1994). Phylogenetic trees were constructed by using three different algorithms, neighbour-joining, maximum-likelihood and maximum-parsimony algorithms; these methods are available in PHYLIP software, version 3.6 (Felsenstein, 2002). Sequence similarity values between the novel strain and related organisms were computed using the FASTA3 program in EBI (http://www.ebi.ac.uk/fasta33/nucleotide. $\mathrm{html}$ ). A bootstrap analysis was performed according to the Kimura two-parameter model (Kimura, 1980) of the neighbour-joining method in the PHYLIP package. DNADNA hybridization was carried out to evaluate the genomic DNA relatedness between strain $\mathrm{EMB} 13^{\mathrm{T}}$ and $R$. limosa EMB $111^{\mathrm{T}}$ using the fluorometric microplate method (Ezaki et al., 1989). Fluorometric data recorded after $30 \mathrm{~min}$ incubation were used for the calculation of a DNA-DNA hybridization value; the DNA relatedness value is the mean of three values.

Phylogenetic analysis based on 16S rRNA gene sequences indicated that strain $\mathrm{EMB}^{\mathrm{T}}{ }^{\mathrm{T}}$ formed a phylogenetic lineage with $R$. limosa $\mathrm{EMB} 111^{\mathrm{T}}$ with $100 \%$ bootstrap value (Fig. 1). The overall topologies of the maximumlikelihood and maximum-parsimony trees were essentially the same as that of the neighbour-joining tree (data not shown). Comparative 16S rRNA gene sequence analysis showed that strain $\mathrm{EMB} 13^{\mathrm{T}}$ was most closely related to $R$. limosa $\mathrm{EMB} 111^{\mathrm{T}}, R$. zeae $\mathrm{NS}^{\mathrm{T}} 2^{\mathrm{T}}$ and $R$. slithyformis ATCC $29530^{\mathrm{T}}$, with sequence similarities of $97.1,93.9$ and $93.6 \%$, respectively. The DNA-DNA relatedness between strain $\mathrm{EMB}^{\mathrm{T}}{ }^{\mathrm{T}}$ and R. limosa $\mathrm{EMB} 111^{\mathrm{T}}$ was about $25 \%$, which is clearly below the $70 \%$ threshold generally accepted for species delineation (Stackebrandt et al., 2002). The physiological, biochemical and phylogenetic properties of strain $\mathrm{EMB} 13^{\mathrm{T}}$ suggest that the isolate should be considered as representing an additional novel species belonging to the genus Runella, for which the name Runella defluvii sp. nov. is proposed.

\section{Description of Runella defluvii sp. nov.}

Runella defluvii (de.flu'vi.i. L. gen. n. defluvii of sewage).

Colonies are slightly raised, circular and salmon pink in colour on R2A agar. Cells are Gram-negative, non-motile

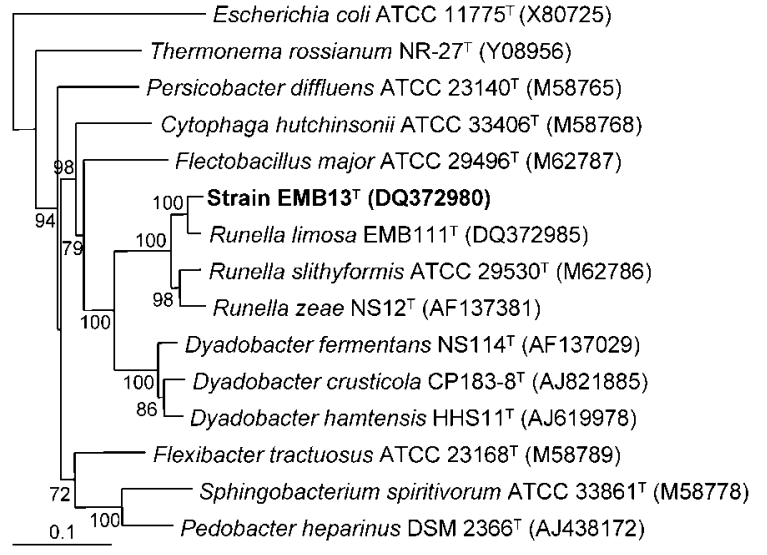

Fig. 1. Neighbour-joining tree showing the phylogenetic relationships based on $16 \mathrm{~S}$ rRNA gene sequences of strain $\mathrm{EMB} 13^{\top}$ and related taxa. Bootstrap values are shown as percentages of 1000 replicates when greater than 50\%. Escherichia coli ATCC $11775^{\top}$ was used as an outgroup. Bar, 0.1 changes per nucleotide position.

rods, $0.5-0.9 \mu \mathrm{m}$ wide and $2.2-6.0 \mu \mathrm{m}$ long at $30{ }^{\circ} \mathrm{C}$ on R2A agar. Growth occurs at $15-40{ }^{\circ} \mathrm{C}$ (optimum, 30$35^{\circ} \mathrm{C}$ ) and at $\mathrm{pH}$ 6.0-9.5 (optimum, $\mathrm{pH}$ 7.5-8.0). Nitrate is not reduced to nitrite. Catalase-positive and oxidasenegative. No anaerobic growth after 7 days at $30{ }^{\circ} \mathrm{C}$ on R2A agar. Tyrosine, Tween 80 and aesculin are hydrolysed, but casein, Tween 20, starch, gelatin and urea are not hydrolysed. Acid is produced from raffinose, myo-inositol, lactose, L-arabinose, D-galactose, D-mannose, D-mannitol and melibiose, but not from D-glucose, D-fructose, arbutin or salicin. Indole, $\mathrm{H}_{2} \mathrm{~S}$ and acetoin are not produced and citrate is not utilized (API 20E). Alkaline phosphatase, trypsin, $\alpha$-chymotrypsin, $N$-acetyl- $\beta$-glucosaminidase and naphthol-AS-BI-phosphohydrolase are produced, but tryptophan deaminase, esterase (C4), lipase (C14) and $\beta$ glucuronidase are not produced. Weak activities are observed for esterase lipase (C8), leucine arylamidase, valine arylamidase, cystine arylamidase, acid phosphatase, $\alpha$-galactosidase, $\beta$-galactosidase, $\alpha$-glucosidase, $\beta$-glucosidase, $\alpha$-mannosidase and $\alpha$-fucosidase (API ZYM). Utilizes glycerol, methyl $\beta$-xyloside, methyl $\alpha$-D-mannoside and aesculin as sole carbon sources but not erythritol, D- or Larabinose, D-xylose, adonitol, galactose, D-glucose, Dfructose, mannose, dulcitol, inositol, mannitol, sorbitol, $\mathrm{N}$-acetylglucosamine, salicin, cellobiose, maltose, lactose, melibiose, sucrose, trehalose, inulin, melezitose, D-raffinose, D-turanose, D- or L-arabitol, gluconate or 2ketogluconate. Weakly utilizes ribose, L-xylose, sorbose, rhamnose, methyl $\alpha$-D-glucoside, amygdalin, arbutin, starch, glycogen, xylitol, $\beta$-gentiobiose, D-lyxose, D-tagatose, D- and L-fucose and 5-ketogluconate (API 50CH). Contains a large amount of phosphatidylethanolamine and small amounts of phosphatidylcholine and an unknown phospholipid as polar lipids. The major isoprenoid quinone is menaquinone-7. The cellular fatty acids are 
iso- $\mathrm{C}_{15: 0}(29.0 \%)$, summed feature $3\left(\mathrm{C}_{16: 1} \omega 7 c\right.$ and/or iso- $\left.\mathrm{C}_{15: 0} 2-\mathrm{OH} ; 20.2 \%\right), \mathrm{C}_{16: 1} \omega 5 c(10.8 \%)$, iso- $\mathrm{C}_{17: 0} 3-$ $\mathrm{OH}(9.2 \%)$, iso- $\mathrm{C}_{15: 0} 3-\mathrm{OH}(7.4 \%), \mathrm{C}_{15: 0}(6.5 \%)$, iso$\mathrm{C}_{15: 1} \mathrm{G}(3.4 \%), \mathrm{C}_{16: 0} 3-\mathrm{OH}(3.3 \%)$, iso- $\mathrm{C}_{13: 0}(2.2 \%)$, $\mathrm{C}_{15: 1} \omega 6 c(1.8 \%), \mathrm{C}_{16: 0}(1.4 \%), \mathrm{C}_{17: 1} \omega 6 c(0.9 \%), \mathrm{C}_{14: 0}$ $(0.8 \%)$, anteiso- $\mathrm{C}_{15: 0}(0.6 \%)$ and unknown ECL 14.959 $(2.7 \%)$. The $\mathrm{G}+\mathrm{C}$ content of the DNA is $40.1 \mathrm{~mol} \%$ (HPLC).

The type strain is $\mathrm{EMB}^{\mathrm{T}}$ (=KCTC $12614^{\mathrm{T}}=\mathrm{DSM}$ $\left.17976^{\mathrm{T}}\right)$, isolated from activated sludge of a domestic wastewater treatment plant.

\section{Acknowledgements}

This study was supported by grants from the MOST/KOSEF to the Environmental Biotechnology National Core Research Center (grant R15-2003-012-02002-0) and to the 21C Frontier Microbial Genomics and Application Center Program (grant MG05-0104-4-0), Ministry of Science \& Technology, Korea. The first three authors were supported by scholarships from the BK21 program, the Ministry of Education and Human Resources Development in Korea.

\section{References}

Chelius, M. K. \& Triplett, E. W. (2000). Dyadobacter fermentans gen. nov., sp. nov., a novel Gram-negative bacterium isolated from surface-sterilized Zea mays stems. Int J Syst Evol Microbiol 50, 751-758.

Chelius, M. K., Henn, J. A. \& Triplett, E. W. (2002). Runella zeae sp. nov., a novel Gram-negative bacterium from the stems of surfacesterilized Zea mays. Int J Syst Evol Microbiol 52, 2061-2063.

Ezaki, T., Hashimoto, Y. \& Yabuuchi, E. (1989). Fluorometric deoxyribonucleic acid-deoxyribonucleic acid hybridization in microdilution wells as an alternative to membrane filter hybridization in which radioisotopes are used to determine genetic relatedness among bacterial strains. Int J Syst Bacteriol 39, 224-229.

Felsenstein, J. (2002). PHYLIP (phylogeny inference package) version 3.6a. Distributed by the author. Department of Genome Sciences, University of Washington, Seattle, USA.

Gomori, G. (1955). Preparation of buffers for use in enzyme studies. Methods Enzymol 1, 138-146.

Jeon, C. O., Lim, J.-M., Lee, J.-M., Xu, L.-H., Jiang, C.-L. \& Kim, C.-J. (2005). Reclassification of Bacillus haloalkaliphilus Fritze 1996 as Alkalibacillus haloalkaliphilus gen. nov., comb. nov. and the description of Alkalibacillus salilacus sp. nov., a novel halophilic bacterium isolated from a salt lake in China. Int J Syst Evol Microbiol 55, 1891-1896.
Kimura, M. (1980). A simple method for estimating evolutionary rates of base substitutions through comparative studies of nucleotide sequences. J Mol Evol 16, 111-120.

Komagata, K. \& Suzuki, K. (1987). Lipid and cell-wall analysis in bacterial systematics. Methods Microbiol 19, 161-207.

Lane, D. J. (1991). 16S/23S rRNA sequencing. In Nucleic Acid Techniques in Bacterial Systematics, pp. 115-175. Edited by E. Stackebrandt \& M. Goodfellow. Chichester: Wiley.

Lanyi, B. (1987). Classical and rapid identification methods for medically important bacteria. Methods Microbiol 19, 1-67.

Larkin, J. M. \& Williams, P. M. (1978). Runella slithyformis gen. nov., sp. nov., a curved, nonflexible, pink bacterium. Int J Syst Bacteriol 28, 32-36.

Leifson, E. (1963). Determination of carbohydrate metabolism of marine bacteria. J Bacteriol 85, 1183-1184.

Lu, S., Park, M., Ro, H.-S., Lee, D. S., Park, W. \& Jeon, C. O. (2006). Analysis of microbial communities using culture-dependent and culture-independent approaches in an anaerobic/aerobic SBR reactor. J Microbiol 44, 155-161.

Park, M., Lu, S., Ryu, S. H., Chung, B. S., Park, W., Kim, C. J. \& Jeon, C. O. (2006). Flavobacterium croceum sp. nov., isolated from activated sludge. Int J Syst Evol Microbiol 56, 2443-2447.

Park, M., Ryu, S. H., Vu, T. H., Ro, H. S., Yun, P. Y. \& Jeon, C. O. (2007). Flavobacterium defluvii sp. nov., isolated from activated sludge. Int J Syst Evol Microbiol 57, 233-237.

Reddy, G. S. N. \& Garcia-Pichel, F. (2005). Dyadobacter crusticola sp. nov., from biological soil crusts in the Colorado Plateau, USA, and an emended description of the genus Dyadobacter Chelius and Triplett 2000. Int J Syst Evol Microbiol 55, 1295-1299.

Ryu, S. H., Nguyen, M. T., Park, W., Kim, C.-J. \& Jeon, C. O. (2006). Runella limosa sp. nov., isolated from activated sludge. Int J Syst Evol Microbiol 56, 2757-2760.

Smibert, R. M. \& Krieg, N. R. (1994). Phenotypic characterization. In Methods for General and Molecular Bacteriology, pp. 607-654. Edited by P. Gerhardt, R. G. E. Murray, W. A. Wood \& N. R. Krieg. Washington, DC: American Society for Microbiology.

Stackebrandt, E., Frederiksen, W., Garrity, G. M., Grimont, P. A. D., Kämpfer, P., Maiden, M. C., Nesme, X., Rosselló-Mora, R., Swings, J. $\&$ other authors (2002). Report of the ad hoc committee for the reevaluation of the species definition in bacteriology. Int J Syst Evol Microbiol 52, 1043-1047.

Tamaoka, J. \& Komagata, K. (1984). Determination of DNA base composition by reversed-phase high-performance liquid chromatography. FEMS Microbiol Lett 25, 125-128.

Thompson, J. D., Higgins, D. G. \& Gibson, T. J. (1994). CLUSTAL W: improving the sensitivity of progressive multiple sequence alignment through sequence weighting, position-specific gap penalties and weight matrix choice. Nucleic Acids Res 22, 4673-4680. 